\title{
Association of MTR, MTRR and MTHFR gene polymorphisms in Non-Syndromic Cleft Lip and Palate in Paediatric patients in Northern India
}

\author{
Rakesh Kumar Chak ${ }^{1}$, Veerendra Prasad ${ }^{2}$, Nisha Singh $^{3}$, Chandrakanta ${ }^{4}$, Richa Khanna ${ }^{5}$, Nitu Nigam ${ }^{6}$ and \\ Aravindhan Arumugam ${ }^{7 *}$ \\ ${ }^{1}$ Professor \& Head, Department of Paediatric and Preventive Dentistry, King George's Medical University, India \\ ${ }^{2}$ Professor, Department of Plastic Surgery, King George's Medical University, India
}

${ }^{3}$ Professor, Department of Obstetrics and Gynaecology, King George's Medical University, India

${ }^{4}$ Professor, Department of Paediatrics, King George's Medical University, India

${ }^{5}$ Professor, Department of Paediatric and Preventive Dentistry, King George's Medical University, India

${ }^{6}$ Assistant Professor, Department of Cytogenetics, King George's Medical University, India

7Junior Resident, Department of Paediatric and Preventive Dentistry, King George's Medical University, India

Submission: February 02, 2021; Published: March 03, 2021

*Corresponding author: Aravindhan Arumugam, Department of Paediatric and Preventive Dentistry, King George's Medical University, India

\begin{abstract}
Non syndromic cleft lip and palate includes a wide spectrum of clinical variability from a simple unilateral lip scar to bilateral cleft lip and cleft palate. Folic acid can prevent the neural tube defects such as cleft lip and palate. Polymorphisms of the folate pathway genes causes disturbed activity of the key enzymes of folate metabolism which may be a contributing factor for the development of cleft lip and palate. Main enzymes of folate pathway such as methionine synthase, methionine synthase reductase and methylene tetrahydrofolate reductase are encoded by MTR, MTRR and MTHFR genes respectively. This research evaluates the association of MTR, MTRR and MTHFR gene polymorphisms in non-syndromic cleft lip and palate in northern Indian children.

Keywords: Non syndromic; Cleft lip and palate; MTR; MTRR; MTHFR; Gene polymorphisms; folate.

Abbreviations: NSCLP: Non-Syndromic Cleft Lip and Palate; MTR: Methionine Synthase Gene; MTRR: Methionine Synthase Reductase Gene; MTHFR: Methylene Tetrahydrofolate Reductase Gene; PCR: Polymerase Chain Reaction; RFLP: Restriction Fragment Length Polymerisation; SNP: Single Nucleotide Polymorphism; DNA: Deoxyribo Nucleic Acid; EDTA: Ethylene Diamine Tetra Acetic Acid; RPM: Rotations per minute; BP: Base pairsf
\end{abstract}

\section{Introduction}

Cleft lip or palate (CL/P) is a common human congenital defect promptly recognized at birth. Despite the variability driven by socioeconomic status and ethnic background, the worldwide prevalence of CL/P is often cited as 1:700 live births [1]. Cleft lip is consistently more common in males at a 2:1 ratio, in contrast to cleft palate which has a similar ratio in favor of females. Unilateral cleft lip shows a 2:1 left predominance [2]. There is geographical variation in the prevalence of cleft in the world. Cleft lip and palate results from failure of fusion of the maxillary processes or palatal shelves, which occur between the $4^{\text {th }}$ and $12^{\text {th }}$ weeks of embryogenesis. Maternal alcohol intake or exposure to tobacco and several chemicals, such as retinoic acid and folate antagonists (e.g., valproic acid), among others, has been shown to be teratogenic, thus representing risk factors to embryos during the first trimester of pregnancy [3]. The involvement of the MTR, $M T R R$, and MTHFR enzymes in folate metabolism and methyl group metabolism makes these enzymes crucial for the maintenance of proper DNA methylation and nucleic acid synthesis. MTR is encoded by the MTR gene and is responsible for the regeneration of methionine from homocysteine and MTR gene mutations may contribute to various diseases, including cardiovascular diseases, cancers, birth defects and congenital anomalies [4]. 
Folic acid supplemented periconceptionally in the mother appears to dramatically reduce the frequency of neural tube defects. However, the mechanism underlying this beneficial effect remains unclear. Genes involved in cellular folate transportation may be prime candidates for folate regulated NTDs. If vitamin supplements namely folic acid and cobalamins were not taken during early pregnancy the risk for CLP could be tripled [5]. In periconceptional folic acid deficiency, the MTHFR C677T thermally labile variant could lead to a risk of CLP that was increased by 10 times [3]. Extensive studies have explored the relationships of gene polymorphisms related to the folic acid/homocysteine metabolic pathway with NSCLP and the results have revealed that the relationships of genetic mutations with NSCLP susceptibility vary between different populations. Conflicting results regarding the MTR A2756G polymorphism and the risk of NSCLP have been reported among Chinese and Indian population. It necessitates the further studies among Indian and Chinese cleft lip and palate population to find the genetic association [6].

Maternal folate deficiency may be a contributing factor to cleft aetiology when maternal family history is observed and offer a possible explanation for the conflicting results of previous studies investigating MTHFR genotype in relation to CLP. Such results would also suggest the importance of collecting parental and grandparental data when evaluating parental effects. A significantly higher mutation frequency of MTHFR in mothers of children with CLP. Thus, the important of periconceptional folate intake were emphasized in these studies and its deficiencies could lead to CLP [7]. So, we correlated the maternal folate intake with genetic polymorphisms of non-syndromic cleft lip and palate in this study. A meta-analysis indicated that the MTRR A66G polymorphism but not the MTR A2756G polymorphism, may increase the maternal risk for neural tube defects among Caucasians [8].

A case control study in Chinese population suggests that MTR A2756G, MTRR A66G, and MTHFR C677T gene polymorphisms were associated with the risk of NSCLP. The MTR A2756G, MTRR A66G, MTHFR C677T and MTHFR A1298C polymorphisms were assessed by polymerase chain reaction-restriction fragment length polymorphism [9]. In addition, a recent study reported that the MTRR A66G polymorphism but not the MTR A2756G polymorphism may contribute to NSCLP in Indian populations [10]. The MTHFR C677T polymorphism is associated with the risk of NSCLP but not with other clefts in the craniofacial region of south Indian population. The TT genotype increased the risk of NSCLP and CT genotype showed a decrease in the risk [11]. These conflicting results in different population suggests further studies in specific population to analyse the prevalence and association of gene polymorphisms in NSCLP. Consanguineous marriage and recurrent abortions in mother are potential risk factors for the development of congenital disorders. In this study we analysed the MTR A2756G, MTRR A66G, MTHFR C677T and A1298C gene polymorphisms in north Indian population to check the prevalence and their association in non-syndromic cleft lip and palate with the history of folate intake, consanguinity and recurrent abortion.

\section{Materials and Methods}

\section{Patient selection}

Patients visiting the outpatient department of Paediatric and Preventive Dentistry, department of Plastic Surgery, department of Obstetrics and Gynaecology and department of Paediatrics, King George's Medical University were screened. The patients were assessed for eligibility as per the inclusion and exclusion criteria.

\section{Inclusion criteria}

a) Patients in the age group 0-15 years.

b) Patients with non-syndromic cleft lip, cleft palate and cleft lip with palate were included in this study.

c) Patients who have undergone surgical correction of nonsyndromic cleft lip, cleft palate and cleft lip with palate were also included in this study.

\section{Exclusion criteria}

a) Cleft lip and palate associated with other congenital disorders or congenital malformations, such as neural tube defects or congenital heart diseases with concomitant cleft lip and palate, kabuki make-up syndrome, Van der Woude syndrome, Meckel syndrome, or velocardiofacial syndrome.

b) Non syndromic cleft lip and palate patients with associated hypertension, coronary heart disease, or other important organ diseases.

c) Patients with history of systemically debilitating diseases like uncontrolled diabetes, immunosuppression, severe asthma etc.

\section{Investigative procedure}

a) Informed consent is taken from the parents or guardians of the patients for participation into the study. The detailed history is taken from the patient/ parents with demographic details.

b) The history includes familial association of cleft lip and palate, religion, region where they belong to, consanguineous marriage, history of any drug intake, recurrent abortions, trauma to mother during pregnancy, thyroid disorder in mother, maternal folic acid deficiency, and folic acid supplement intake.
i. Sample collection and DNA isolation
ii. Gene polymorphism analysis by PCR- RFLP procedure
iii. Data collection and statistical analysis

\section{i. Sample collection and DNA isolation:}

a) $2 \mathrm{ml}$ of blood samples were collected by venepuncture in EDTA tubes (Figure $1 \& 2$ ) and DNA will be extracted from whole blood using the DNA extraction kit according to the manufacturers' instructions. (QiAgen DNA extraction kit). 


\section{Advances in Dentistry \& Oral Health}

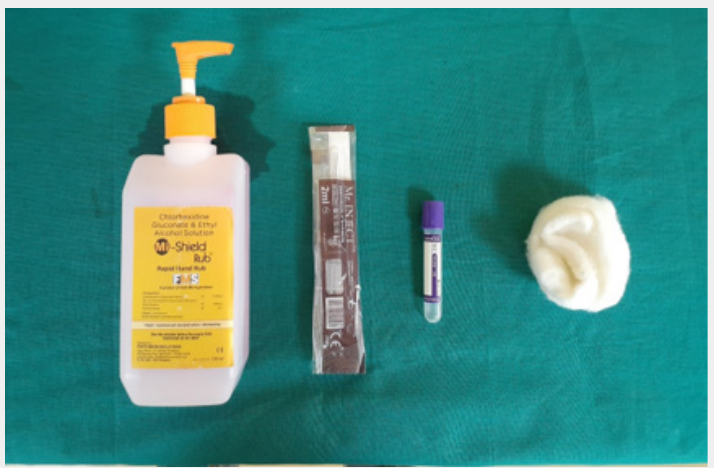

Figure 1: Armamentarium for blood collection.

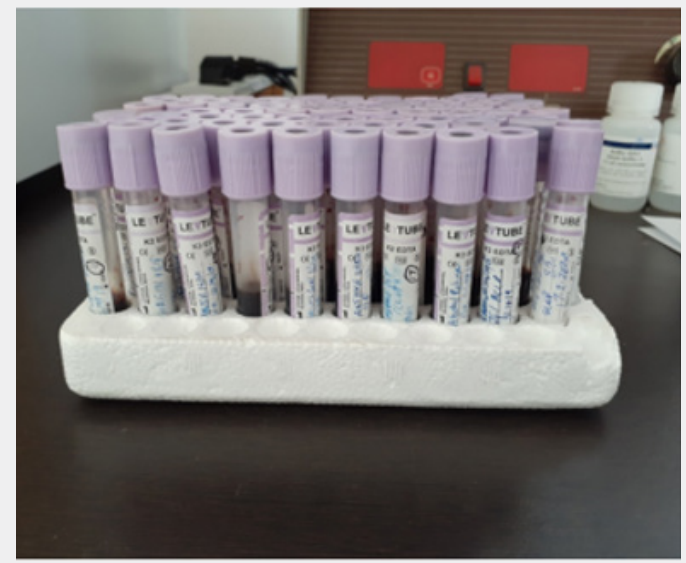

Figure 2: Stored blood samples in EDTA vials.

b) The genotyping was carried out in patients suffering from Cleft Lip with or Without Cleft Palate. A total 4 SNPs were analysed (Table 1). All MTR, MTRR, and MTHFR Gene polymorphisms were analyzed for their correlation with Cleft Lip with or Without Cleft Palate. PCR was performed in a gradient thermocycler using thin walled $0.2 \mathrm{ml}$ PCR tubes.

Table 1: Primer Sequences and Genotyping Reaction Conditions for the Detection of MTR, MTRR, and MTHFR Gene Polymorphisms

\begin{tabular}{|c|c|c|c|c|}
\hline SNP Locus & Primer Sequence & Ta $\left({ }^{\circ} \mathrm{C}\right)$ & Restriction Enzyme & Product Size (bp \\
\hline MTR A2756G & $\begin{array}{l}\text { F5'-CATGGAAGAATATGAAGATATTAGAC-3' } \\
\text { R5'-GAACTAGAAGACAGAAATTCTCTA-3' }\end{array}$ & $56^{\circ} \mathrm{C}$ & HaelII & $\begin{array}{c}\text { A:189 bp } \\
\text { G: } 159 \mathrm{bp}, 30 \mathrm{bp}\end{array}$ \\
\hline MTRR A66G & $\begin{array}{l}\text { F5'-GCAAAGGCCATCGCAGAAGACAT-3' } \\
\text { R5'-AAACGGTAAAATCCACTGTAACGG-3' }\end{array}$ & $58.2^{\circ} \mathrm{C}$ & NdeI & $\begin{array}{l}\text { A: } 126,25 \mathrm{bp} \\
\text { G: } 151 \mathrm{bp}\end{array}$ \\
\hline MTHFR C677T & $\begin{array}{l}\text { F5'-TGAAGGAGAAGGTGTCTGCGGGA-3' } \\
\text { R5'-AGGACGGTGCGGTGAGAGTG-3' }\end{array}$ & $610 \mathrm{C}$ & Hinf & $\begin{array}{l}\text { T: } 175 \text { and } 23 \mathrm{bp} \\
\text { C: } 198 \mathrm{bp}\end{array}$ \\
\hline MTHFR A1298C & $\begin{array}{l}\text { F5'-AAGGAGGAGCTGCTGCTGAAGATG-3' } \\
\text { R5'-CTTTGCCATGTCCACAGCATG-3' }\end{array}$ & $610 \mathrm{C}$ & MboII & $\begin{array}{l}\text { A: } 182,28 \text { and } 27 \mathrm{bp} \\
\text { C: } 210 \text { and } 27 \mathrm{bp}\end{array}$ \\
\hline
\end{tabular}

(bp: base pairs, Ta: annealing temperature, F: forward, R: reverse, SNP: single nucleotide polymorphism, A: adenine, G: guanine, T: thymine, C: cytosine).

\section{ii. PCR based amplification assay:}

a) The polymorphisms of the MTR, MTRR, MTHFR gene were genotyped using a polymerase chain reaction-restriction fragment length polymorphism (PCR-RFLP) method. PCR was carried out on a Biometra T Robot Thermocycler (PCR) (LabRepCo, LLC. USA) using the respective primers. b) The MTR A2756G, MTRR A66G, MTHFR C677T and A1298C genotypes is sequenced and analyzed by polymerase chain reaction-restriction fragment length polymorphism (PCR-RFLP). The PCR-amplified products were digested overnight at $37^{\circ} \mathrm{C}$ with specific restriction enzymes (HaeIII for MTR A2756G, Ndel for MTRR A66G, Hinf for MTHFR C677T, and MboII for MTHFR A1298C) in a total volume of 20 


\section{Advances in Dentistry \& Oral Health}

$\mathrm{mL}$ containing $17 \mathrm{~mL}$ PCR-amplified products, ddH20, $2 \mathrm{~mL}$ 10 . reaction buffer and $1 \mathrm{~mL}$ restriction enzyme $(10 \mathrm{U} / \mathrm{mL})$. Six percent polyacrylamide gel electrophoresis was used to separate the enzyme-digested products. The genotypes were determined according to the enzyme map. c) Gel electrophoresis pictures of PCR based amplification assay for genotypes MTR A2756G, MTRR A66G, MTHFR C677T and MTHFR A1298C were shown in Figure 3-6 respectively.

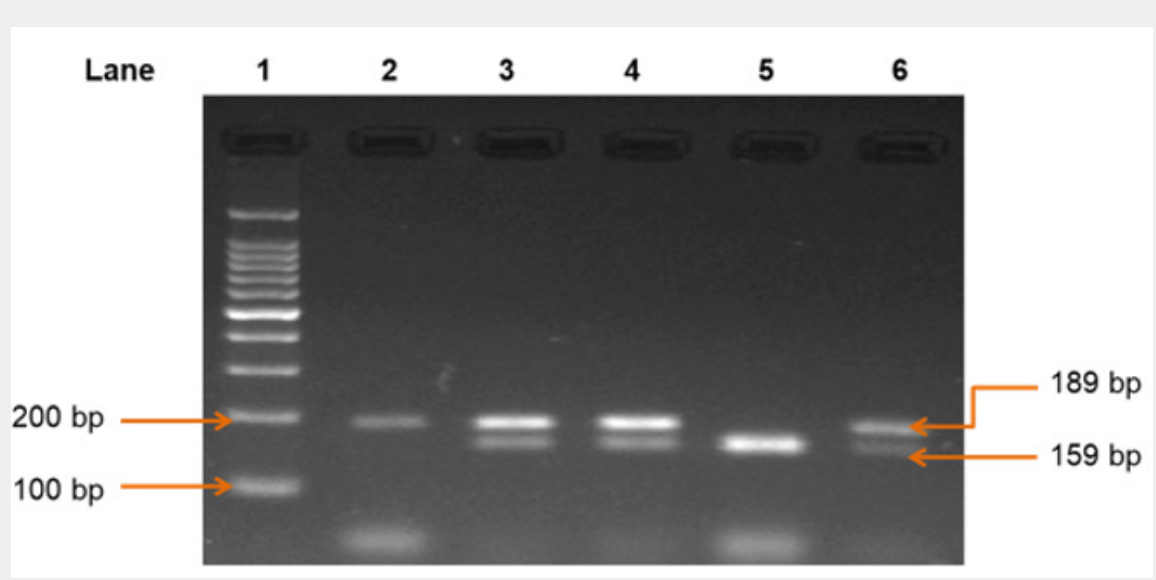

Figure 3: Gel electrophoresis picture of MTR A2756G gene polymorphism by PCR- RFLP method.

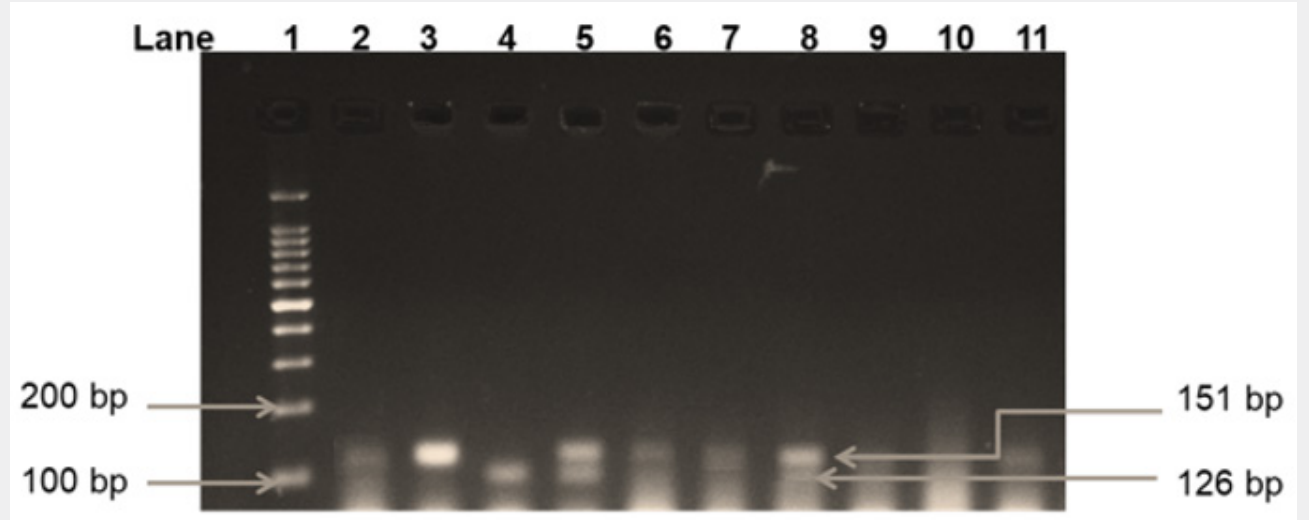

Figure 4: Gel electrophoresis picture of MTRR A66G gene polymorphism by PCR- RFLP method.

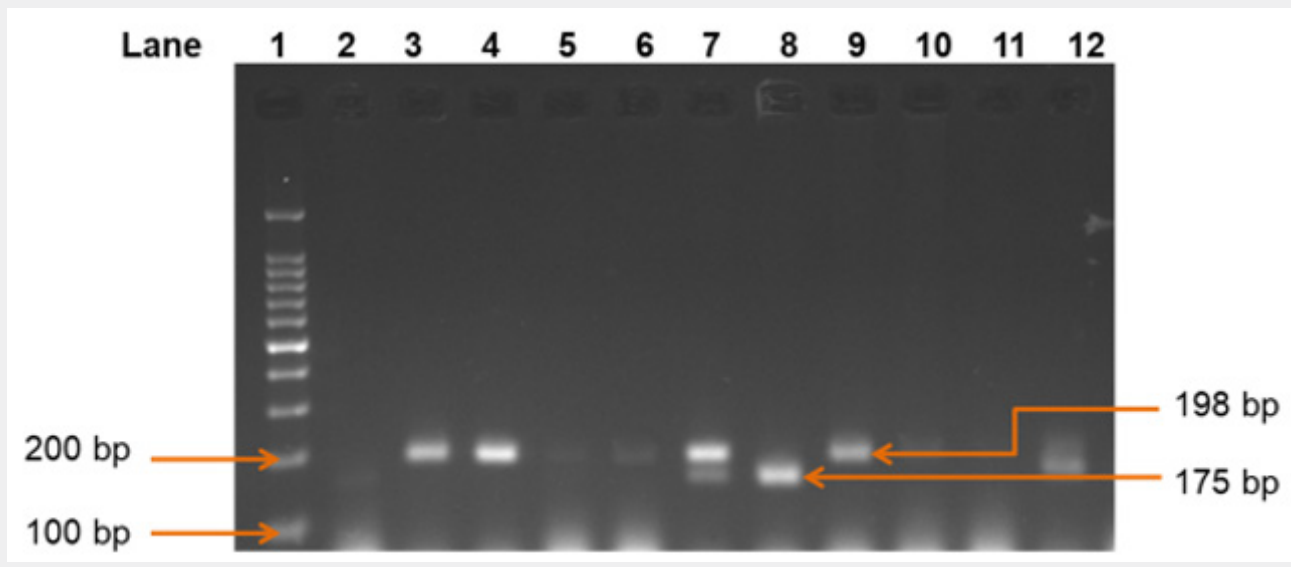

Figure 5: Gel electrophoresis picture of MTHFR C677T gene polymorphism by PCR- RFLP method. 


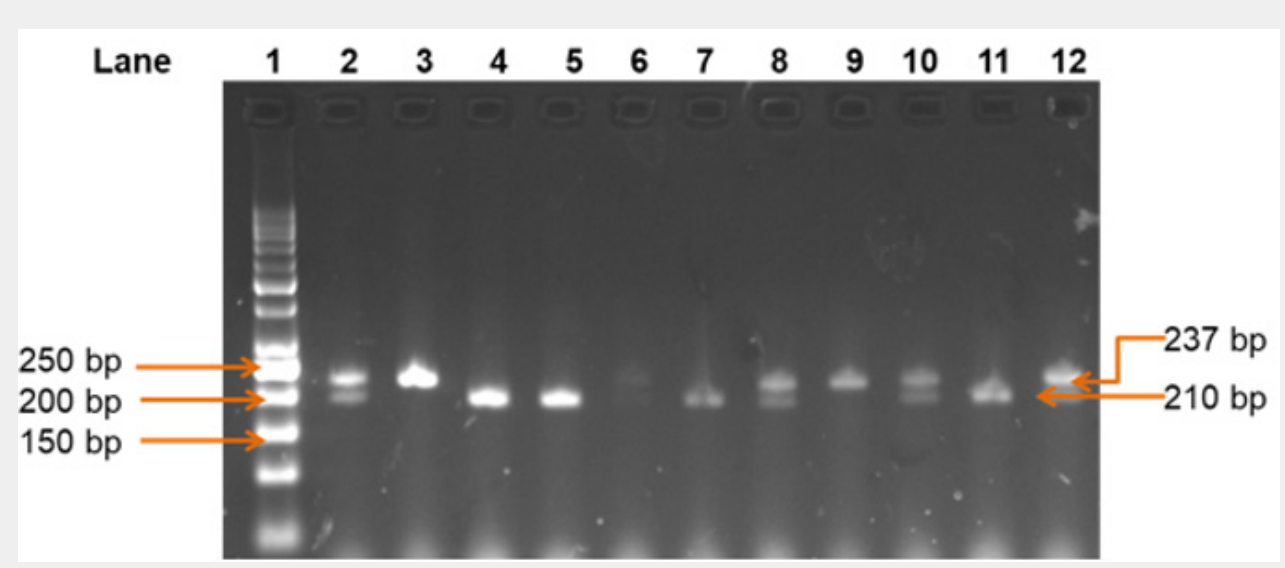

Figure 6: Gel electrophoresis picture of MTHFR A1298C gene polymorphism by PCR- RFLP method.

\section{Results}

A total of 164 patients of both genders were included in the study. Table 2 shows age distribution of patients and parents. Mean age of the patients enrolled in this study was $11.85 \pm 3.99$ years which ranges from 4 months of age to 15 years of age. Mean age of fathers and mothers of the patients included in the study were $43.97 \pm 7.16$ years and $37.46 \pm 6.55$ years respectively. Table 3 shows gender distribution of patients of this study with the equal distribution of male and female study population $(50 \%$ male[n=82] and 50\% female[n=82]). Table 4 \& Figure 7 show the percentage of different types of cleft lip and/or palate patients in the total study population. In the total of 164 patients, cleft lip patients were the least prevalence with $1.8 \%(n=3)$ and cleft lip and palate patients were the most prevalence with $90.9 \%$ $(n=149)$. Unilateral cleft lip and palate of the left side is the most common among type in this population (56.7\%, $\mathrm{n}=93) .11 .1 \%$ $(n=7)$ patients have the positive family history with their siblings affected with cleft lip and palate. Mothers of the patients have the positive history of recurrent abortion of $9.8 \%(n=16) .73 .2 \%$ $(n=120)$ of mothers did not take any form of folic acid and iron supplement during their pregnancy. Table 5 \& Figure 8 show the genotype and allele prevalence of genes studied. AA genotype is more prevalent in MTR A2756G gene $(62.2 \%, \mathrm{n}=102)$ and MTRR A66G gene (58.5\%, $\mathrm{n}=96)$.TT genotype is more prevalent in MTHFR C677T gene (78.0\%, $\mathrm{n}=128)$. MTHFR A1298C gene shows more AC genotype prevalence $(51.2 \%, \mathrm{n}=84)$.

Table 2: Patient's age and age of parents.

\begin{tabular}{|c|c|c|c|c|c|c|c|}
\hline Age & Mean & Standard Deviation & Median & Minimum & Maximum & Range & Valid N \\
\hline Patient's age & 11.85 & 3.99 & 14.00 & .40 & 15.00 & 14.60 & 164 \\
\hline father's age & 43.97 & 7.16 & 45.00 & 25.00 & 70.00 & 45.00 & 164 \\
\hline mother's age & 37.46 & 6.55 & 38.00 & 23.00 & 55.00 & 32.00 & 164 \\
\hline
\end{tabular}

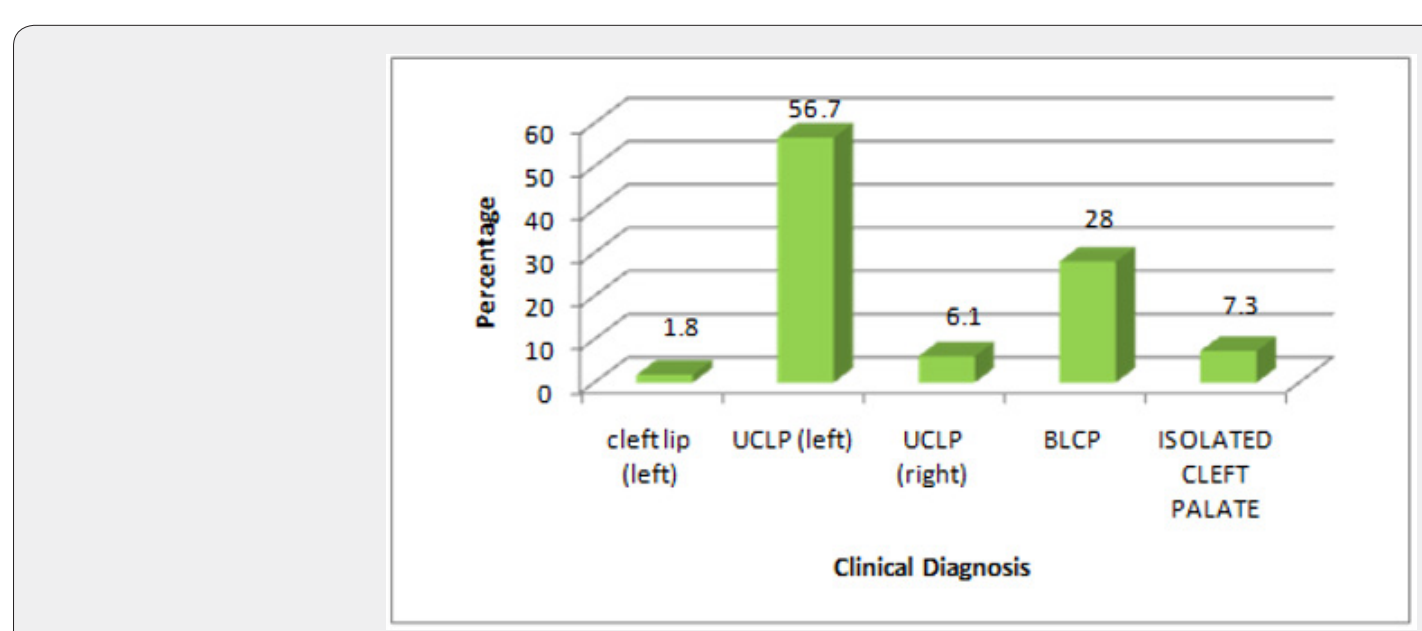

Figure 7: Prevalence of different clinical types of cleft 
Table 3: Gender distribution of patients.

\begin{tabular}{|c|c|c|}
\hline Gender & N & Percent \\
\hline Male & 82 & 50.0 \\
\hline Female & 82 & 50.0 \\
\hline Total & 164 & 100.0 \\
\hline
\end{tabular}

Table 4: Clinical types of cleft lip and/or palate patients.

\begin{tabular}{|c|c|c|}
\hline Clinical Diagnosis & N & Percent \\
\hline cleft lip (left) & 164 & 1.8 \\
\hline UCLP (left) & 93 & 56.7 \\
\hline UCLP (left) & 10 & 6.1 \\
\hline BLCP & 46 & 28.0 \\
\hline ISOLATED CLEFT PALATE & 12 & 7.3 \\
\hline Total & 164 & 100.0 \\
\hline
\end{tabular}

Table 5: Percentage of genotype and allele prevalence in MTR, MTRR, MTHFR genes.

\begin{tabular}{|c|c|c|c|}
\hline \multicolumn{2}{|c|}{ Genotypes } & N & \% \\
\hline MTR A2756G & AA & 102 & $62.2 \%$ \\
\hline & AG & 58 & $35.4 \%$ \\
\hline & GG & 4 & $2.4 \%$ \\
\hline & AG+GG & 62 & $37.8 \%$ \\
\hline
\end{tabular}

\begin{tabular}{|c|c|c|c|}
\hline & A & 262 & $79.8 \%$ \\
\hline & G & 66 & $20.1 \%$ \\
\hline \multirow[t]{6}{*}{ MTRR A66G } & $\mathrm{AA}$ & 96 & $58.5 \%$ \\
\hline & AG & 36 & $22.0 \%$ \\
\hline & GG & 32 & $19.5 \%$ \\
\hline & $\mathrm{AG}+\mathrm{GG}$ & 68 & $41.5 \%$ \\
\hline & $\mathrm{A}$ & 228 & $69.5 \%$ \\
\hline & G & 100 & $30.5 \%$ \\
\hline \multirow[t]{6}{*}{ MTHFRC677T } & $\mathrm{CC}$ & 6 & $3.7 \%$ \\
\hline & CT & 30 & $18.3 \%$ \\
\hline & TT & 128 & $78.0 \%$ \\
\hline & $\mathrm{CT}+\mathrm{TT}$ & 158 & $96.3 \%$ \\
\hline & $\mathrm{C}$ & 42 & $12.8 \%$ \\
\hline & $\mathrm{T}$ & 286 & $87.2 \%$ \\
\hline \multirow[t]{6}{*}{ MTHFR A1298C } & $\mathrm{AA}$ & 58 & $35.4 \%$ \\
\hline & $\mathrm{AC}$ & 84 & $51.2 \%$ \\
\hline & $\mathrm{CC}$ & 22 & $13.4 \%$ \\
\hline & $\mathrm{AC}+\mathrm{CC}$ & 106 & $64.6 \%$ \\
\hline & A & 200 & $60.9 \%$ \\
\hline & $\mathrm{C}$ & 128 & $39.1 \%$ \\
\hline
\end{tabular}

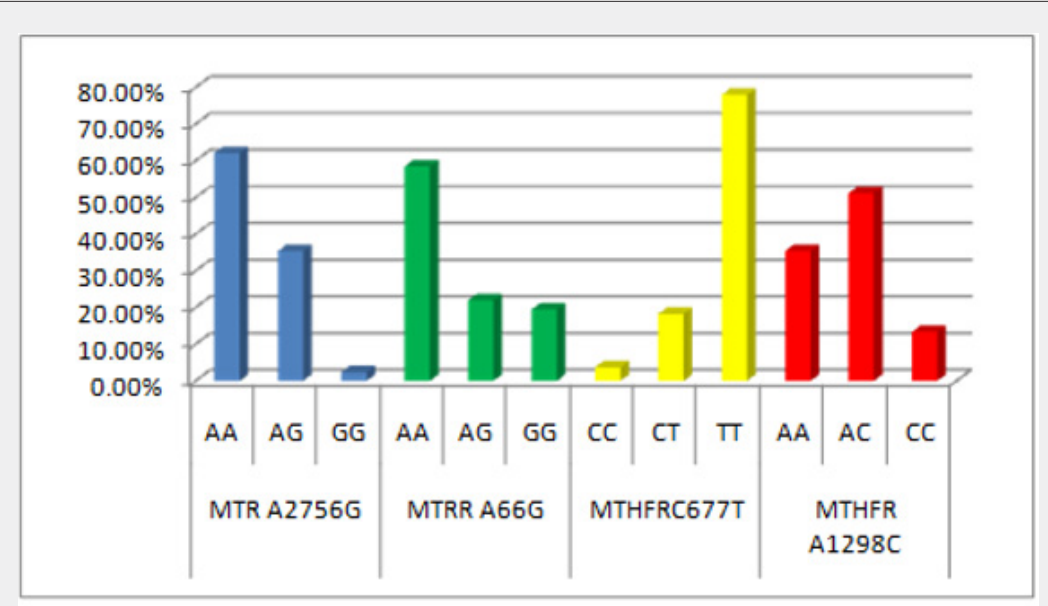

Figure 8: Prevalence of genotypes of MTR, MTRR, MTHFR polymorphisms.

Table 6 \& Figure 9 show the significant association of MTHFR A1298C polymorphism and gestational folic acid intake $(\mathrm{p}<$ 0.001) with AC genotype predominance. MTR A2756G, MTRR A66G, MTHFR C677T gene polymorphism are not associated with gestational folic acid intake. Table 7 shows the prevalence of various types of clefts with gene polymorphisms. MTRA2756Ggene polymorphism is associated with cleft lip and palate $(\mathrm{p}<0.001)$ with AA genotype predominance. MTRR A66G gene polymorphisms is also associated $(\mathrm{p}=0.047)$ with cleft lip and palate. Table 8 shows the association of gene polymorphisms with history of recurrent abortions in mother. MTHFR C677T gene polymorphism shows the significant $(\mathrm{p}=0.010)$ association with non-syndromic cleft lip and palate, while other gene polymorphisms are not statistically significant with cleft lip and palate when compared with recurrent abortions ( $p>0.3$ ). Table 9 shows the prevalence of family history of consanguinity in study population. $34.1 \%(n=56)$ 
patients had the consanguineous parents of total 164 patients. Table 10 \& Figure 10 show the association of cleft lip and palate gene polymorphisms with the consanguinity. MTR A2756G gene $(\mathrm{p}=0.032)$ and AA genotype predominance in noted MTR A2756G gene polymorphism. MTHFR C677T gene polymorphism is also associated with the consanguinity $(\mathrm{p}=0.049)$. polymorphism is significant association with the consanguinity

Table 6: Association of maternal folic acid intake and gene polymorphisms.

\begin{tabular}{|c|c|c|c|c|c|c|}
\hline & & \multicolumn{4}{|c|}{ History of Gestational Folic Acid Intake } & \multirow{3}{*}{ p-value } \\
\hline & & \multicolumn{2}{|c|}{ Yes } & \multicolumn{2}{|c|}{ No } & \\
\hline & & $\mathbf{N}$ & $\%$ & $\mathbf{N}$ & $\%$ & \\
\hline \multirow{3}{*}{ MTR A2756G } & AA & 26 & $59.1 \%$ & 76 & $63.3 \%$ & 0.353 \\
\hline & $\mathrm{AG}$ & 18 & $40.9 \%$ & 40 & $33.3 \%$ & \\
\hline & GG & 0 & $.0 \%$ & 4 & $3.3 \%$ & \\
\hline \multirow{3}{*}{ MTRR A66G } & AA & 30 & $68.2 \%$ & 66 & $55.0 \%$ & 0.055 \\
\hline & $\mathrm{AG}$ & 4 & $9.1 \%$ & 32 & $26.7 \%$ & \\
\hline & GG & 10 & $22.7 \%$ & 22 & $18.3 \%$ & \\
\hline \multirow{3}{*}{ MTHFRC677T } & $\mathrm{CC}$ & 0 & $.0 \%$ & 6 & $5.0 \%$ & 0.179 \\
\hline & CT & 6 & $13.6 \%$ & 24 & $20.0 \%$ & \\
\hline & TT & 38 & $86.4 \%$ & 90 & $75.0 \%$ & \\
\hline \multirow{3}{*}{ MTHFR A1298C } & $\mathrm{AA}$ & 14 & $31.8 \%$ & 44 & $36.7 \%$ & $<0.001$ \\
\hline & $\mathrm{AC}$ & 16 & $36.4 \%$ & 68 & $56.7 \%$ & \\
\hline & $\mathrm{CC}$ & 14 & $31.8 \%$ & 8 & $6.7 \%$ & \\
\hline
\end{tabular}

\section{H/O gestational Folic acid intake}

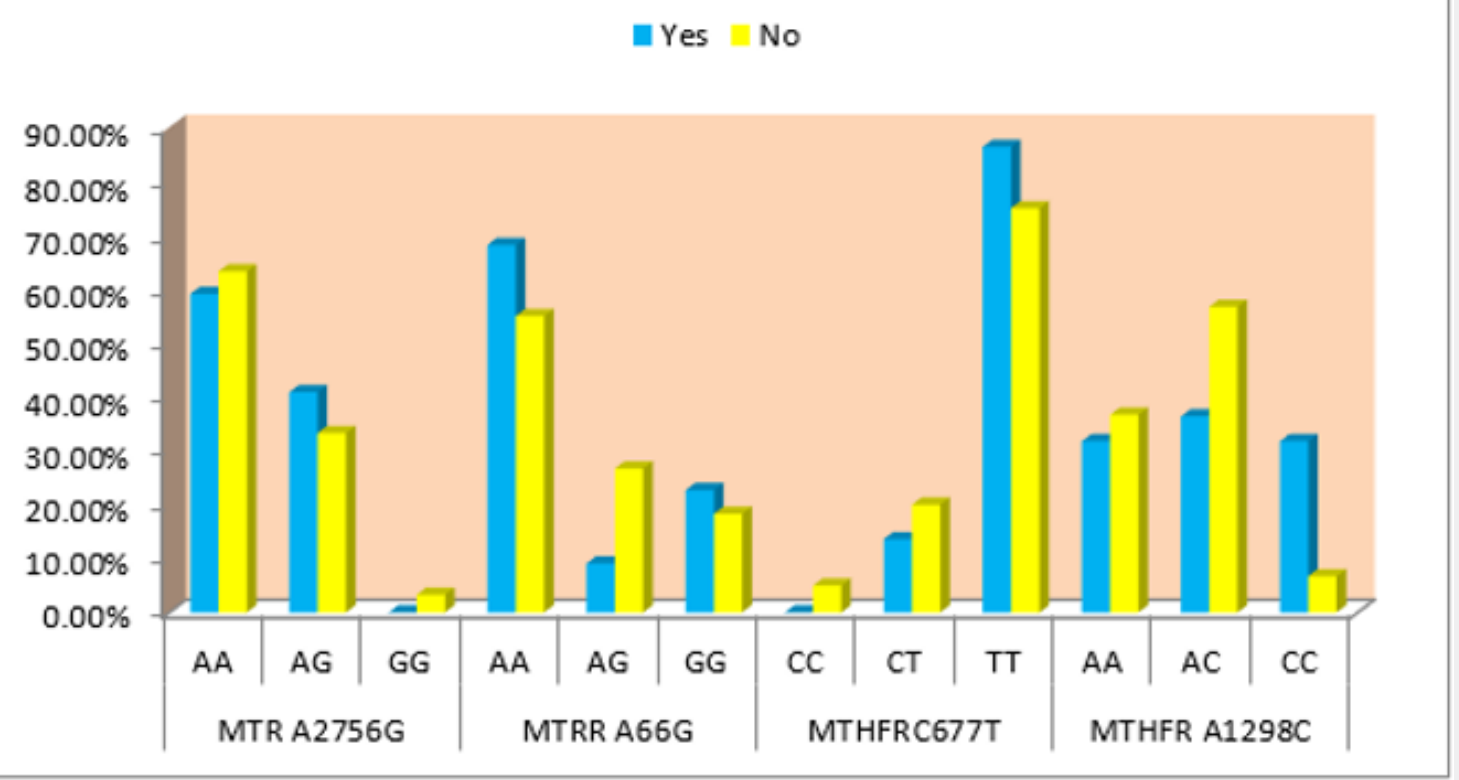

Figure 9: Association of gene polymorphism and gestational folic acid intake. 


\section{Advances in Dentistry \& Oral Health}

Table 7: Prevalence of gene polymorphisms in various types of clefts.

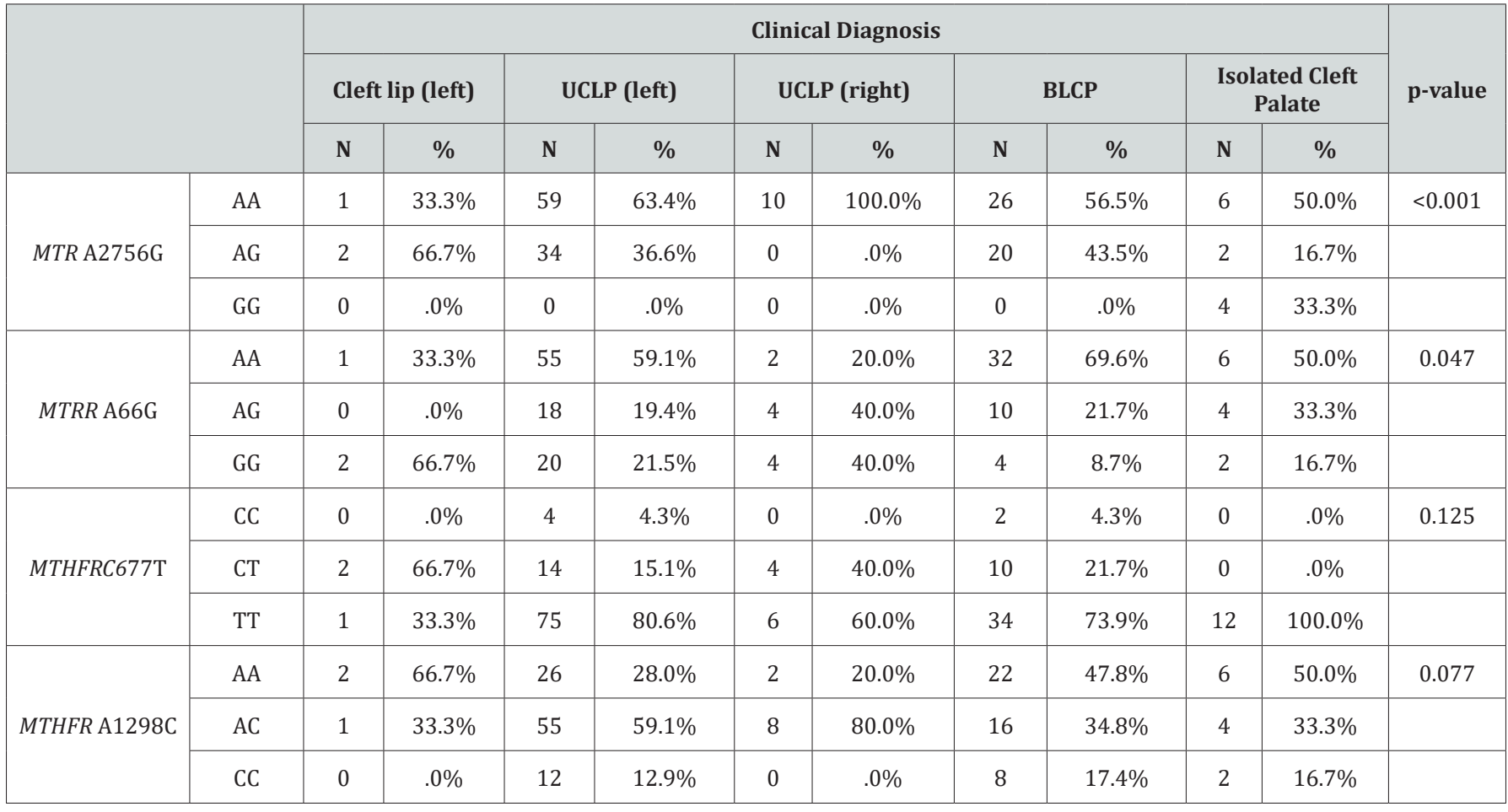

Table 8: Association of gene polymorphisms with recurrent abortions.

\begin{tabular}{|c|c|c|c|c|c|c|}
\hline & & \multicolumn{4}{|c|}{ History of Recurrent Abortion } & \multirow{3}{*}{ p-value } \\
\hline & & \multicolumn{2}{|c|}{ Yes } & \multicolumn{2}{|c|}{ No } & \\
\hline & & $\mathbf{N}$ & $\%$ & $\mathrm{~N}$ & $\%$ & \\
\hline \multirow{3}{*}{ MTR A2756G } & AA & 12 & $75.0 \%$ & 90 & $60.8 \%$ & 0.487 \\
\hline & $\mathrm{AG}$ & 4 & $25.0 \%$ & 54 & $36.5 \%$ & \\
\hline & GG & 0 & $.0 \%$ & 4 & $2.7 \%$ & \\
\hline \multirow{3}{*}{ MTRR A66G } & AA & 10 & $62.5 \%$ & 86 & $58.1 \%$ & 0.594 \\
\hline & $\mathrm{AG}$ & 2 & $12.5 \%$ & 34 & $23.0 \%$ & \\
\hline & GG & 4 & $25.0 \%$ & 28 & $18.9 \%$ & \\
\hline \multirow{3}{*}{ MTHFRC677T } & CC & 2 & $12.5 \%$ & 4 & $2.7 \%$ & 0.010 \\
\hline & $\mathrm{CT}$ & 6 & $37.5 \%$ & 24 & $16.2 \%$ & \\
\hline & TT & 8 & $50.0 \%$ & 120 & $81.1 \%$ & \\
\hline \multirow{3}{*}{ MTHFR A1298C } & AA & 4 & $25.0 \%$ & 54 & $36.5 \%$ & 0.314 \\
\hline & $\mathrm{AC}$ & 8 & $50.0 \%$ & 76 & $51.4 \%$ & \\
\hline & CC & 4 & $25.0 \%$ & 18 & $12.2 \%$ & \\
\hline
\end{tabular}

Table 9: Prevalence of consanguinity in study population.

\begin{tabular}{|c|c|c|}
\hline Consanguinity & N & Percent \\
\hline Yes & 56 & 34.1 \\
\hline No & 108 & 65.9 \\
\hline Total & 164 & 100.0 \\
\hline
\end{tabular}


Table 10: Association of consanguinity with the gene polymorphisms.

\begin{tabular}{|c|c|c|c|c|c|c|}
\hline & & \multicolumn{4}{|c|}{ Consanguinity } & \multirow{3}{*}{ p-value } \\
\hline & & \multicolumn{2}{|c|}{ Yes } & \multicolumn{2}{|c|}{ No } & \\
\hline & & $\mathbf{N}$ & $\%$ & $\mathbf{N}$ & $\%$ & \\
\hline \multirow{3}{*}{ MTR A2756G } & AA & 42 & $75.0 \%$ & 60 & $55.6 \%$ & 0.032 \\
\hline & $\mathrm{AG}$ & 14 & $25.0 \%$ & 44 & $40.7 \%$ & \\
\hline & GG & 0 & $.0 \%$ & 4 & $3.7 \%$ & \\
\hline \multirow{3}{*}{ MTRR A66G } & AA & 30 & $53.6 \%$ & 66 & $61.1 \%$ & 0.101 \\
\hline & $\mathrm{AG}$ & 10 & $17.9 \%$ & 26 & $24.1 \%$ & \\
\hline & GG & 16 & $28.6 \%$ & 16 & $14.8 \%$ & \\
\hline \multirow{3}{*}{ MTHFRC677T } & $\mathrm{CC}$ & 4 & $7.1 \%$ & 2 & $1.9 \%$ & 0.049 \\
\hline & $\mathrm{CT}$ & 14 & $25.0 \%$ & 16 & $14.8 \%$ & \\
\hline & TT & 38 & $67.9 \%$ & 90 & $83.3 \%$ & \\
\hline \multirow{3}{*}{ MTHFR A1298C } & AA & 18 & $32.1 \%$ & 40 & $37.0 \%$ & 0.823 \\
\hline & $\mathrm{AC}$ & 30 & $53.6 \%$ & 54 & $50.0 \%$ & \\
\hline & $\mathrm{CC}$ & 8 & $14.3 \%$ & 14 & $13.0 \%$ & \\
\hline
\end{tabular}

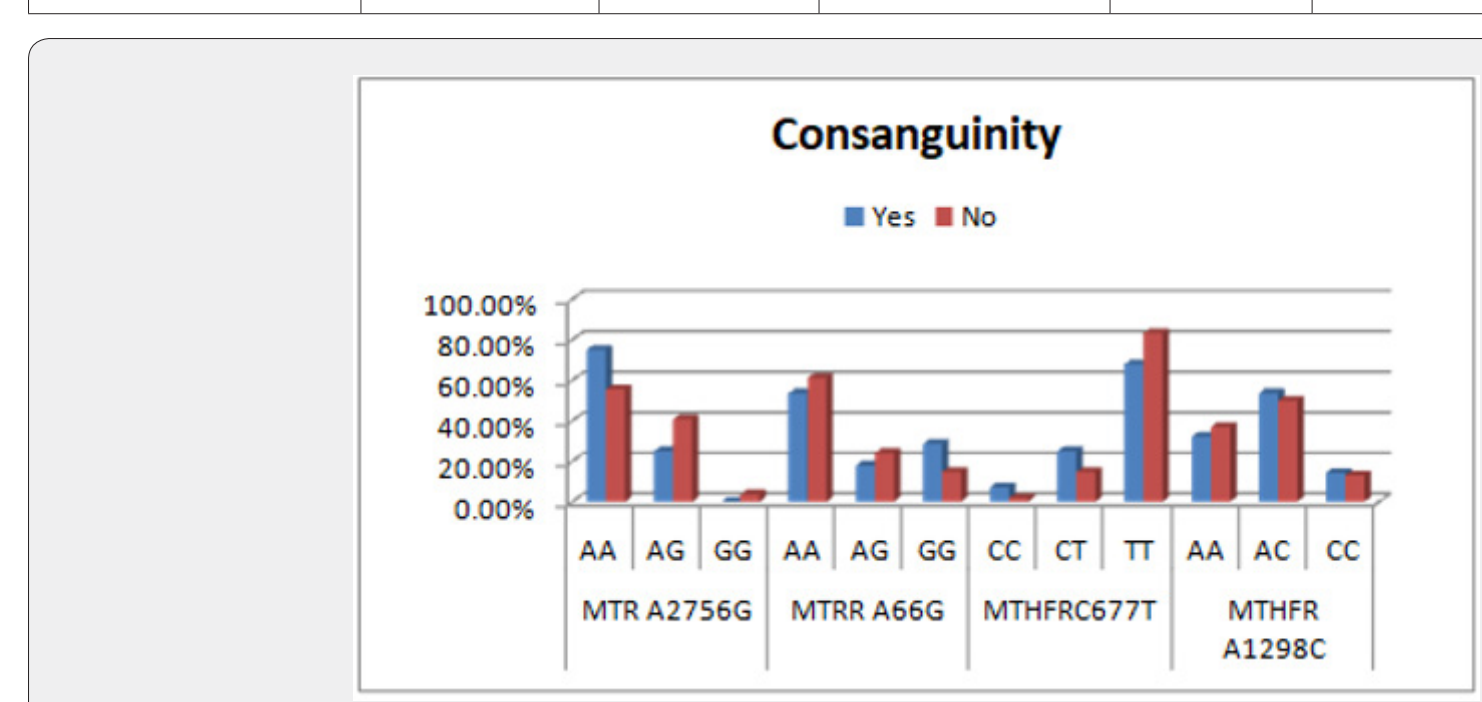

Figure 10: Association of gene polymorphism and consanguinity.

\section{Discussion}

Oro facial cleft is the most common developmental anomaly of the head and neck region and second most common congenital anomaly in the body next to congenital heart diseases [12]. Cleft lip and palate cause negative impact on psychosocial life of the children and their families. Cleft lip and palate affect phonation, auditory ability and oro facial development. The etiology of the disease is very complex that is the genetic and environmental interactions. Folic acid is essential to prevent the neural tube defects. Key enzymes of folic acid pathway are maintained by MTR, MTRR, MTHFR genes. Many studies have found the association of these gene polymorphisms with non-syndromic cleft lip and palate, but there are population-based variations in the association [9]. Our study focuses genetic polymorphisms of folic acid pathway genes MTR, MTRR, MTHFR in north Indian population at a tertiary level of care institute of Uttar Pradesh. The incidence and geographical distribution of clefts varies across the world. This may be due to variation in the prevalence of birth and under reporting. According to a study, 3 children with cleft are born in every hour and a total of 26,950 new cases are reported from India every year [7].

The present study demonstrates the prevalence of cleft lip is $1.8 \%$ and cleft lip and palate is $90.9 \%$, isolated cleft palate is $7.3 \%$ which coincides with the previous study by Menezes LM 
et al. and a study conducted in Japan [13]. Whereas in a study conducted in south Indian population, the frequency of Cleft lip only was more than Cleft lip with palate and isolated cleft palate and in Republic of Korea, cleft palate was more common than the cleft lip with palate [14]. These findings suggest that there is a demographic variation in the frequency of different phenotypes. Studies show different sex distribution also in the prevalence of clefts where studies in various countries observed a male predominance [7]. Our study demonstrated Cleft lip with palate to be the predominant type of orofacial clefts and a high male to female sex ratio among CPL (1.1:1) and CL patients (1.5:1). In contrast, the ratio of cleft palate was more frequent in females with a high female: male ratio (1.2:1). These results are similar with the previous study conducted by Diwana et al. [15]. It was found that unilateral clefts were more common than bilateral clefts. Our study also demonstrated left-sided clefts to be more common than right sided clefts. In this study, unilateral cleft lip and palate is more prevalent $(62.8 \%)$ and the unilateral cleft lip and palate of left side is more common (56.1\%). The reason for the left side laterality is not proven.

Previous studies showed that there is a definite influence of consanguinity in the occurrence of clefts as it is suggested that this association is probably related with a recessive genetic component and environmental factors. In the present study, the consanguinity was positive in around $34.10 \%(n=56)$. The findings of the study were similar to the studies done by Dwidedi et al. [15] in a tertiary hospital in Dehradun and other studies conducted in Saudi Arabia and Iran where the consanguinity was positive in around 48.9\%, 54.4\%, and 61.6\%, respectively [15]. Neela PK et al. [16] concluded that the consanguinity is the major risk factor for the development of cleft lip and palate. In our study approximately $60 \%$ of the clefts born to consanguineous parents are seen in males in present study the association of consanguinity with MTR A2756G polymorphism with statistically significant value $(\mathrm{p}=0.032)$. MTHFR C677T polymorphism is also significant when the consanguinity is considered $(\mathrm{p}=0.049)$.

One of the contributing factors for the occurrence of MTHFR gene polymorphisms may be recurrent abortions. MTHFR C677T gene polymorphism is found to be associated with the parent mothers who had the history of recurrent abortions $(\mathrm{p}<0.010)$ in our study. It has been previously reported that taking folic acid supplementation at early pregnancy stage reduces the cleft palate risk and peri conceptional usage of folate reduced the miscarriage risk and prevents the occurrence of birth defects [17]. But the effect of folic acid, a cofactor for MTHFR enzyme action is protective in some populations Mossey et al. [18] but ineffective in some others van Rooji et al. [19]. Lopez cartes et al. [20] found that these polymorphisms alter homocysteine levels and reduce enzymatic activity, which may lead to DNA damage associated with folate deficiency that may further contribute to the development of non-syndromic cleft lip and palate. In our study out of 164 patients, mothers of 120 (73.2\%) patients did not take any folic acid and iron supplements during the pregnancy period. This may be a cause of polymorphism of MTHFR A1298C gene $(\mathrm{p}<0.001)$ and depressed action of methylene tetra hydro folate reductase enzyme leading to clefts though it was found to be statistically insignificant. This may be due to less sample size and possible other environment-gene interactions.

MTR A2756G gene polymorphism is highly associated with all clinical types of non-syndromic cleft lip and palate patients of the study population $(\mathrm{p}<0.001)$ which was similar to studies by Denis aslar et al. and Wang et al. who found that MTR A2756G gene polymoprphism is highly associated with non-syndromic cleft lip in Turkish population and with cleft lip and palate in Chinese population respectively while no statistically significant correlation was found in the study conducted in Brazil $[9,21,22]$. In the present study there is suggested geographical variation and undiscovered gene -environment interaction may be attributing to MTR A2756G gene polymorphism in Indian population. In our study population the MTRR A66G is also associated with cleft lip and palate prevalence $(\mathrm{p}<0.047)$. The results coincide with the previous studies by Wang et al.9 in Chinese population and by Vandana Rai et al. [23] in Eastern India (2019). In contrast study conducted by Nasri K et al. [24] shows MTRR A66G is not associated with non-syndromic cleft lip and palate. There is geographical variation in the prevalence of MTRR A66G polymorphism.

The present study correlates the environmental factors such as maternal folic acid intake, thyroid disorder in mother, maternal alcohol consumption and maternal drug intake etc., but there are some limitations to the study. First, the limited sample size of this study may have biased the associations of the MTR A2756G, MTRR A66G, MTHFR C677T and MTHFR A1298C gene polymorphisms with the non-syndromic cleft lip and palate risk. Second, this study did not consider the possibility of linkage disequilibrium between SNP-SNP interactions. These limitations could be overcome with more specific studies with larger samples and with more advanced molecular genetics technology. Future studies will uncover additional mechanistic insights and potential gene-environment interactions of the MTR A2756G, MTRR A66G, MTHFR C677T and MTHFR A1298C gene polymorphisms with non-syndromic cleft lip and palate.

\section{Conclusion}

Based on the observations and findings of the present study, the following conclusions were drawn:

i. Unilateral cleft lip and palate of left side were found 56\% that was more prevalent in paediatric patients in northern India among cleft lip and palate patients.

ii. Unilateral cleft lip and palate of right side were found $6.1 \%$, unilateral cleft lip $1.8 \%$, bilateral cleft lip with palate $28 \%$ and isolated cleft palate were found $7.3 \%$ in paediatric patients in northern India among cleft lip and palate patients. 
iii. MTR A2756G and MTRR A66G gene polymorphisms were found associated with non-syndromic cleft lip and palate patients of northern India.

iv. MTHFR A1298C gene polymorphism was found associated with no maternal folate intake by mothers of nonsyndromic cleft lip and palate patients.

v. MTR A2756G and MTHFR C677T gene polymorphisms were found associated with non-syndromic cleft lip and palate with consanguineous parents.

vi. MTHFR C677T gene polymorphism was found associated with history of recurrent abortion in mothers of non-syndromic cleft lip and palate.

However, further studies are needed to validate the findings and to explore possible gene- environmental interactions.

\section{Acknowledgement}

I would like to convey my gratitude to the Research cell, King George's Medical University for the financial support of this research work through the intra mural grants.

\section{References}

1. Carinci F, Pezetti F, Scapoli L, Martinelli M, Avantaggiato A (2003) Recent developments in Orofacial Cleft Genetics. J Craniofac Surg 14(2): 130-143.

2. James WH (2000) Are oral clefts a consequence of maternal hormone imbalance? Evidence from the sex ratios of sibs of probands. Teratology 62(5): 342-345.

3. Prescott NJ, Winter RM, Malcolm S (2002) Maternal MTHFR genotype contributes to the risk of nonsyndromic cleft lip and palate. J Med Genet 39(5): 368-369.

4. Weiner AS, Gordeeva LA, Voronina EN (2012) Polymorphisms in folatemetabolizing genes and risk of having an offspring with congenital anomalies in the West Siberian region of Russia: a case-control study. J Prenat Diagn 32(11): 1041-1048.

5. Shaw GM, Nelson V, Carmichael SL, Lammer EJ, Finnell RH, et al. (2002) Maternal periconceptional vitamins: Interactions with selected factors and congenital anomalies? Epidemiology 13(6): 625-630.

6. Brito LA, Cruz LA, Rocha KM (2011) Genetic contribution for nonsyndromic cleft lip with or without cleft palate (NS CL/P) in different regions of Brazil and implications for association studies. American Journal of Medical Genetics 155(7): 1581-1587.

7. Mossey PA, Little J, Munger RG, Dixon MJ, Shaw WC (2009) Cleft lip and palate. The Lancet 374(9703): 1773-1785.

8. Ouyang S, Li Y, Liu Z (2013) Association between MTR A2756G and MTRR A66G polymorphisms and maternal risk for neural tube defects: a meta-analysis. J Gene 515(2): 308-312.

9. Wang Wei, Jiao, Hui X, Ping X, Yu X, et al. (2016) MTR, MTRR, and MTHFR Gene Polymorphisms and Susceptibility to Nonsyndromic Cleft Lip with or Without Cleft Palate. J Genetic testing and molecular biomarkers 10: 1089.
10. Murthy J, Gurramkondab VB, Lakkakula BV (2015) Genetic variant in MTRR A66G, but not MTR A2756G, is associated with risk of nonsyndromic cleft lip and palate in Indian population. J Oral Maxillofac Surg 27: 782-785.

11. Jose BA, Mokhasi V, Subramani SA, Shashirekha M (2020) MTHFR C677T Polymorphism and risk of nonsyndromic cleft in craniofacial region in a South Indian Population. J anatomical society of India 5:1013.

12. Bender PL (2000) Genetics of cleft lip and palate. Journal of Pediatric Nursing 15(4): 242-249.

13. Menezes LM, Rizzatto SM, Azeredo F, Vargas DA (2010) Characteristics and distribution of dental anomalies in a Brazilian cleft population. Rev Odont Sci 25: 137-141.

14. Nagase Y, Natsume N, Kato T, Hayakawa T (2010) Epidemiological analysis of cleft lip and/or palate by cleft pattern. J Maxillofac Oral Surg 9(4): 389-395.

15. Diwana VK, Gupta G, Chauhan R, Mahajan K, Mahajan A, et al. (2019) Clinical and epidemiological profile of patients with cleft lip and palate anomaly: 10-year experience from a tertiary care center in the subHimalayan state of Himachal Pradesh in Northern India. J Nat Sc Biol Med 10(1): 82-86.

16. Neela PK, Reddy SG, Husain A, Mohan V (2019) Association of cleft lip and/or palate in people born to consanguineous parents: A 13 -year retrospective study from a very high-volume cleft center. J Cleft Lip Palate Craniofac Anomal 6(1): 33-37.

17. Elavenil P, Murugavel C, Kannadasan K, Krishnakumar Raja V B, Gnanam A, et al. (2010) Folic acid in cleft lip, alveolus and palate prevention: Awareness among dental professionals. Indian J Dent Res 21(3): 360-363.

18. Mossey P, Castilla E (2001) Global registry and database on craniofacial anomalies in Proceedings of the World Health Organization Registry Meeting on Craniofacial Anomalies, Bauru, Brazil.

19. Van Rooij IA, Vermeij Keers C, Kluijtmans LA, Ocké MC, Zielhuis GA, et al. (2003) Does the interaction between maternal folate intake and the methylenetetrahydrofolate reductase polymorphisms affect the risk of cleft lip with or without cleft palate? Am J Epidemiol 157(1): 583-591.

20. Cortes AL, Koupermann GJ, Munoz MJ (2013) Genetic polymorphisms in MTHFR (C677T, A1298C), MTR (A2756G) and MTRR (A66G) genes associated with pathological characteristics of prostate cancer in the Ecuadorian population. Am J Med Sci 346(6): 447-454.

21. Aslar D, Ozdiler E, Altug AT, Tastan H (2013) Determination of Methylenetetrahydrofolate Reductase (MTHFR) gene polymorphism in Turkish patients with nonsyndromic cleft lip and palate. International Journal of Pediatric Otorhinolaryngology 77(7): 1143-1146.

22. Brandalize E, Bandinelli JB, Borba TM, Félix I, Roisenberg (2007) Polymorphisms in genes MTHFR, MTR and MTRR are not risk factors for cleft lip/palate in South Brazil. Brazilian Journal of Medical and Biological Research 40(6): 787-791.

23. Rai V (2018) Strong Association of C677T Polymorphism of Methylenetetrahydrofolate Reductase Gene with Nosyndromic Cleft Lip/Palate (nsCL/P). Indian J Clin Biochem 33(1): 5-15.

24. Nasri K, Midani F, Kallel A (2019) Association of MTHFR C677T, MTHFR A1298C, and MTRR A66G Polymorphisms with Neural Tube Defects in Tunisian Parents. Pathobiology 86(4): 190-200. 
This work is licensed under Creative Commons Attribution 4.0 License DOI: 10.19080/ADOH.2021.14.555877
Your next submission with Juniper Publishers will reach you the below assets

- Quality Editorial service

- Swift Peer Review

- Reprints availability

- E-prints Service

- Manuscript Podcast for convenient understanding

- Global attainment for your research

- Manuscript accessibility in different formats ( Pdf, E-pub, Full Text, Audio)

- Unceasing customer service

Track the below URL for one-step submission https://juniperpublishers.com/online-submission.php 